Prepared for the U.S. Department of Energy

under Contract DE-AC05-76RL01830

\title{
Development of $(\mathrm{Mn}, \mathrm{Co})_{3} \mathrm{O}_{4}$ Protection Layers for Ferritic Stainless Steel Interconnects
}
ZG Yang
GG Xia
SP Simner
JW Stevenson
$P$ Singh

July 2005

Pacific Northwest

NATIONAL LABORATORY

Proudly Operated by Battelle Since 1965 


\title{
DISCLAIMER
}

This report was prepared as an account of work sponsored by an agency of the United States Government. Neither the United States Government nor any agency thereof, nor Battelle Memorial Institute, nor any of their employees, makes any warranty, express or implied, or assumes any legal liability or responsibility for the accuracy, completeness, or usefulness of any information, apparatus, product, or process disclosed, or represents that its use would not infringe privately owned rights. Reference herein to any specific commercial product, process, or service by trade name, trademark, manufacturer, or otherwise does not necessarily constitute or imply its endorsement, recommendation, or favoring by the United States Government or any agency thereof, or Battelle Memorial Institute. The views and opinions of authors expressed herein do not necessarily state or reflect those of the United States Government or any agency thereof.

\author{
PACIFIC NORTHWEST NATIONAL LABORATORY \\ operated by \\ BATTELLE \\ for the \\ UNITED STATES DEPARTMENT OF ENERGY \\ under Contract DE-AC05-76RL01830
}

Printed in the United States of America
Available to DOE and DOE contractors from the Office of Scientific and Technical Information,
P.O. Box 62, Oak Ridge, TN 37831-0062;
ph: (865) 576-8401
fax: $(865)$ 576-5728
email: reports@adonis.osti.gov

\begin{abstract}
Available to the public from the National Technical Information Service, U.S. Department of Commerce, 5285 Port Royal Rd., Springfield, VA 22161 ph: (800) 553-6847 fax: $(703) 605-6900$ email: orders@ntis.fedworld.gov online ordering: http://www.ntis.gov/ordering.htm
\end{abstract}

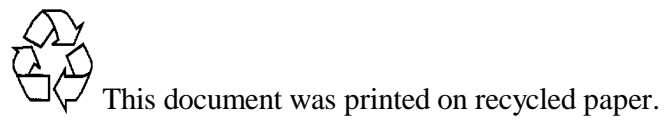




\section{Development of $(\mathrm{Mn}, \mathrm{Co})_{3} \mathrm{O}_{4}$ Protection Layers for Ferritic Stainless Steel Interconnects}

ZG Yang

SP Simner
GG Xia

JW Stevenson

July 2005

Prepared for the U.S. Department of Energy under Contract DE-AC05-76RL01830

Pacific Northwest National Laboratory Richland, Washington 99352 


\section{Development of $(\mathrm{Mn}, \mathrm{Co})_{3} \mathrm{O}_{4}$ Protection Layers for Ferritic Stainless Steel Interconnects}

\section{Executive Summary}

A spinel-based surface protection layer has been developed for alloy SOFC current collectors and bi-polar gas separators. The $(\mathrm{Mn}, \mathrm{Co})_{3} \mathrm{O}_{4}$ spinel with a nominal composition of $\mathrm{Mn}_{1.5} \mathrm{Co}_{1.5} \mathrm{O}_{4}$ demonstrates an excellent electrical conductivity and thermal expansion match to ferritic stainless steel interconnects. A slurry-coating technique provides a viable approach for fabricating protective layers of the spinel onto the steel interconnects. Thermally grown protection layers of $\mathrm{Mn}_{1.5} \mathrm{Co}_{1.5} \mathrm{O}_{4}$ have been found not only to significantly decrease the contact resistance between a LSF cathode and stainless steel interconnect, but also inhibit the sub-scale growth on the stainless steel. The combination of the inhibited sub-scale growth, good thermal expansion matching between the spinel and the stainless steel, and the closed-pore structure contribute to the excellent structural and thermomechanical stability of these spinel protection layers, which was verified by a long-term thermal-cycling test. The spinel protection layers can also act effectively to prevent outward diffusion of chromium from the interconnect alloy, preventing subsequent chromium migration into the cathode and contact materials. PNNL is currently engaged in studies intended to optimize the composition, microstructure, and fabrication procedure for the spinel protection layers.

\section{Introduction}

Given the reduction in solid oxide fuel cell (SOFC) operating temperatures to the 600$800^{\circ} \mathrm{C}$ temperature range, it has become possible to consider cost-effective high temperature oxidation-resistant alloys as replacements for conventional lanthanum chromite ceramics for construction of interconnects in SOFC stacks [1-3]. Chromia-forming ferritic stainless steels are considered to be among the most promising candidate materials due to their electrically conducting oxide scale, appropriate thermal expansion behavior, and low cost [3-6]. However, several issues potentially hinder their application, including increasing electrical resistance over time, and the migration of chromium via chromia scale evaporation into SOFC cathodes [7-10], which can lead to degradation in cell electrochemical performance [9-13]. Newly developed alloys such as Crofer22 APU, which is protected at elevated temperatures via formation of a 
unique scale comprised of a $(\mathrm{Mn}, \mathrm{Cr})_{3} \mathrm{O}_{4}$ spinel top layer and chromia or chromia-rich sub-layer [14-16], may offer some improvement in this regard due to the lower volatility of Cr from spinel than from chromia. However, volatility measurements at PNNL indicate that the chromium volatility from the spinel may be only a factor of 2 lower than that from chromia $\left(\right.$ at $850^{\circ} \mathrm{C}$ in air with $3 \% \mathrm{H}_{2} \mathrm{O}$ ), so Cr volatility from the spinel as well as any exposed chromia that is not covered by the spinel layer, particularly during the early stages of oxidation, may still result in an unacceptable degradation in cell performance [13,16-18]. Also, it appears that a further improvement in long-term scale stability is needed, particularly for SOFC stacks with an operating temperature $>700^{\circ} \mathrm{C}[16,19,20]$.

As an alternative approach to bulk alloy modification, the interconnect can be surfacemodified via application of a protection layer of conductive oxide(s) on the cathode-side. The protection layer is intended to serve as a barrier to both chromium cation outward and oxygen anion inward diffusion, so that it can decrease the alloy oxidation kinetics, mitigate or even prevent chromium migration from the chromium-containing alloy substrate, and minimize the interfacial contact area specific resistance (ASR) between the cathode and the interconnect by limiting the growth of the Cr-based oxide scale, which has relatively low conductivity. Accordingly, the material(s) selected for the protection layer should possess high electrical conductivity coupled with low chromium cation diffusivity. Low oxygen ion diffusivity is also desirable to limit oxidation of the substrate alloy and therefore the subsequent growth of a chromia or chromia-rich scale or interlayer between the protection layer and the bulk alloy. In addition, the thermal expansion behavior of the protection layer material should match that of the substrate alloy and its scale to enhance thermomechanical integrity, particularly during thermal cycling.

Reported examples of protection layers include overlay coatings of conductive perovskite compositions, such as Sr doped lanthanum manganite, ferrite and chromite, which are often used as cathode and interconnect materials in SOFCs [21-24]. These coatings help lower the interfacial contact resistance, but cell performance may still be degraded by chromium migration from either chromium-containing perovskites (e.g. ( $\left.\mathrm{La}, \mathrm{Sr}) \mathrm{CrO}_{3}\right)$ or non-chromium-containing compositions via chromium cation diffusion through the coatings [9,25]. Other potential challenges associated with perovskite overlay coatings include limited thermomechanical stability due to extensive sub-scale growth resulting from oxygen ion inward diffusion. Spinel 
protective layers have also been investigated. Previous work of Larring and Norby [25] on Plansee Ducrolloy $\left(\mathrm{Cr}-5 \% \mathrm{Fe}-1 \% \mathrm{Y}_{2} \mathrm{O}_{3}\right)$, an interconnect alloy for high temperature (900$\left.1,000^{\circ} \mathrm{C}\right) \mathrm{SOFCs}$, indicated that a $(\mathrm{Mn}, \mathrm{Co})_{3} \mathrm{O}_{4}$ spinel layer could be a promising barrier to chromium migration. PNNL has investigated thermal growth of $(\mathrm{Mn}, \mathrm{Co})_{3} \mathrm{O}_{4}$ spinel layers, with a nominal composition of $\mathrm{Mn}_{1.5} \mathrm{Co}_{1.5} \mathrm{O}_{4}$, onto candidate ferritic stainless steels for interconnect applications in SOFCs [26-30]. Both short and long term tests were carried out, demonstrating the effectiveness of the spinel protection layers in improving the metallic interconnect surface stability, mitigating chromium migration, and minimizing interfacial ASR.

This report summarizes PNNL's ongoing efforts on the development, characterization, and testing of $(\mathrm{Mn}, \mathrm{Co})_{3} \mathrm{O}_{4}$ spinel-based protection layers for application in the electrochemically active area of the SOFC current collector and gas separator. Coating chemistry, fabrication details, properties, and test results are presented.

\section{Structure and Properties of $(\mathrm{Mn}, \mathrm{Co})_{3} \mathrm{O}_{4}$ Spinels}

An ideal spinel oxide consists of a cubic close-packed configuration of $\mathrm{O}^{2-}$ ions with metal cations filling one eighth of the tetrahedral sites and one-half of the octahedral sites. Due to lattice distortion, the cubic spinel often transforms to a tetragonal spinel. This is particular true for $(\mathrm{Mn}, \mathrm{Co})_{3} \mathrm{O}_{4}$ or $\mathrm{Mn}_{1+\delta} \mathrm{Co}_{2-\delta} \mathrm{O}_{4}(-1.0 \leq \delta \leq 2.0)$ systems. Naka, et al [31], reported that, for $0.3<\delta<1.9$, cubic spinel co-existed with the tetragonal spinel, while generally a single phase of cubic spinel was found for $\delta$ in the range of -0.9 0.3. Consistent with those results, the primary spinel prepared and studied at PNNL, which had a nominal composition of $\mathrm{Mn}_{1.5} \mathrm{Co}_{1.5} \mathrm{O}_{4}$, was found by XRD analysis (see Figure 1) to consist of two phases, $\mathrm{MnCo}_{2} \mathrm{O}_{4}$ and $\mathrm{Mn}_{2} \mathrm{CoO}_{4}$, reported in JCPDS as \#18-1237 [34] and \#23-0408 [35], respectively. $\mathrm{MnCo}_{2} \mathrm{O}_{4}$ is a cubic spinel [31-33], with Mn occupying octahedral interstitial sites and Co occupying both tetrahedral and octahedral interstitial sites in the close packed oxygen ion lattice; while $\mathrm{Mn}_{2} \mathrm{CoO}_{4}$ possesses a tetragonal spinel structure [35]. To further verify the structure of the synthesized " $\mathrm{Mn}_{1.5} \mathrm{Co}_{1.5} \mathrm{O}_{4}$ " spinel, spinels with a $\mathrm{Mn} / \mathrm{Co}$ ratio of 1:2, i.e. $\mathrm{MnCo}_{2} \mathrm{O}_{4}$, and a ratio of 2:1, i.e. $\mathrm{Mn}_{2} \mathrm{CoO}_{4}$, were prepared. XRD analyses on these two compounds indicated that the XRD pattern of the synthesized $\mathrm{MnCo}_{2} \mathrm{O}_{4}$ matched with JCPDS \#18-1237, while the synthesized $\mathrm{Mn}_{2} \mathrm{CoO}_{4}$ matched with JCPDS \#23-0408. Thus the synthesized $\mathrm{Mn}_{1.5} \mathrm{Co}_{1.5} \mathrm{O}_{4}$ spinel was a dual phase material comprised of cubic $\mathrm{Mn}_{1+\delta} \mathrm{Co}_{2-\delta} \mathrm{O}_{4}$ and tetragonal $\mathrm{Mn}_{2-\varepsilon} \mathrm{Co}_{1+\varepsilon} \mathrm{O}_{4} . \delta$ and $\varepsilon$ represent a small 
deviation and are reported [31] to be less than 0.3 and 0.1 for the cubic and tetragonal spinels, respectively. (For simplicity, $\mathrm{MnCo}_{2} \mathrm{O}_{4}$ and $\mathrm{Mn}_{2} \mathrm{CoO}_{4}$ are used in this report to represent the cubic and tetragonal spinels, respectively). A similar combination of spinels was also observed by Aukrust and Muan during their phase-diagram study of the cobalt oxide - manganese oxide system in air [36].

As shown in Figure 2, the $\mathrm{Mn}_{1.5} \mathrm{Co}_{1.5} \mathrm{O}_{4}$ spinel demonstrated a good thermal expansion match to ferritic stainless steels such as Crofer22 APU and AISI430, as well as perovskite cathode compositions such as $\mathrm{La}_{0.8} \mathrm{Sr}_{0.2} \mathrm{FeO}_{3}$ and $\mathrm{La}_{0.8} \mathrm{Sr}_{0.2} \mathrm{FeO}_{3}$. Electrical conductivity tests on the $\mathrm{Mn}_{1.5} \mathrm{Co}_{1.5} \mathrm{O}_{4}$ spinel (see Figure 3) indicated an electrical conductivity of $\sim 60 \mathrm{Scm}^{-1}$ at $800^{\circ} \mathrm{C}$ in air, which is 3 4 orders of magnitude higher than $\mathrm{Cr}_{2} \mathrm{O}_{3}$ [38], and 2 3 orders higher than $\mathrm{MnCr}_{2} \mathrm{O}_{4}$ [37], which is the dominant phase in the top layer of scales grown on Mn-containing oxidation resistance alloys such as Crofer22 APU.

\section{Fabrication of Spinel Protection Layers}

Several approaches are being pursued at PNNL as potential means of fabricating an adherent spinel protection layer on ferritic stainless steels. One approach that has proven successful is slurry coating. Figure 4 shows a flow chart of the slurry coating process, which starts with powder synthesis and is followed by slurry preparation, coating, and a subsequent heat treatment in a reducing environment. The spinel protection layer is finally formed via thermal growth during heat treatment in air. Two powder synthesis approaches were used:

O Solid-state reaction of $\mathrm{MnCO}_{3}$ and $\mathrm{Co}_{3} \mathrm{O}_{4}$

o Glycine-nitrate combustion synthesis process (GNP) [39].

The two synthesis approaches generated powders with different properties which greatly affected the quality of the spinel protection layer and its performance. In particular, the glycine-nitrate process yielded finer, more homogeneous powders than the solid-state approach, leading to improved quality and performance of the spinel protection layers.

To synthesize the spinel via the glycine-nitrate process, appropriate amounts of $\mathrm{Mn}\left(\mathrm{NO}_{3}\right)_{3}$ and $\mathrm{Co}\left(\mathrm{NO}_{3}\right)_{3}$ solutions were mixed with glycine and then slowly heated to the combustion point to form the precursor ash. The ash was calcined in air at $800^{\circ} \mathrm{C}$ for 4 hours, attrition-milled, and then fabricated into a screen-printing ink by mixing it with a binder system (Ferro BV-111-2) on a three-roll mill. The ink was applied onto stainless steel coupons by 
painting or screen-printing (e.g., 165mesh screen, $0.05 \mathrm{~mm}$ emulsion). After being dried in an oven in air at $80^{\circ} \mathrm{C}$ for $1 \sim 2$ hours, the coated stainless steel coupons were heat-treated in an $\mathrm{Ar} / 3 \% \mathrm{H}_{2} \mathrm{O} / 2.75 \% \mathrm{H}_{2}$ environment at $800^{\circ} \mathrm{C}$ for 2 hours or more. During the heat-treatment in the reducing environment, the organic binder and solvent were removed and the spinel was reduced into $\mathrm{Co}$ and $\mathrm{MnO}$, as confirmed by the XRD analysis shown in Figure 5(a). SEM analysis (see Figure 6(a)) revealed a uniform, porous layer comprised of $\mathrm{MnO}$ and metal $\mathrm{Co}$, as well as a thin oxide scale grown between that layer and the substrate Crofer22 APU. (Note that the manganese cobaltite spinels are not stable in fuel environments, and their application as a protection layer is limited to the cathode-side of metallic interconnects). During subsequent oxidation in air, the $\mathrm{MnO}$ and Co reacted with oxygen to re-form the spinel phases. This is confirmed by the XRD analysis shown in Figure 5(b) that shows a protection layer grown in air at $800^{\circ} \mathrm{C}$ after 100 hours. The pattern in Figure 5(b) matched very well with that of as-synthesized $\mathrm{Mn}_{1.5} \mathrm{Co}_{1.5} \mathrm{O}_{4}$ powder (Figure 1(b)). A cross-section SEM image (Figure 6(b)) after the oxidizing heattreatment shows that the spinel protection layer was well bonded to the Crofer22 APU substrate via an $\sim 1.0 \mu \mathrm{m}$ thick sub-scale layer that was grown between the spinel protection layer and the metal substrate. A significant amount of (apparently closed) porosity is present in the spinel layer. The densification of the spinel layer from the highly porous layer of $\mathrm{MnO}$ and $\mathrm{Co}$ is attributed to a sintering process that is enhanced by the spinel formation reactions occurring during the oxidizing heat-treatment. Thus it appears that the reducing heat treatment is an important intermediate step for the thermal growth of spinel protection layers with good adhesion to the ferritic stainless steel. The closed pore microstructure in the protection layer may also be beneficial by providing strain tolerance to improve thermomechanical stability during SOFC operation. As no obvious boundary was discernible between the sub-scale layer and the spinel protection layer, it appears that the Mn-Co spinel and the native oxide scale grown on Crofer22 APU, which is comprised of $(\mathrm{Mn}, \mathrm{Cr})_{3} \mathrm{O}_{4}$ spinel and $\mathrm{Cr}_{2} \mathrm{O}_{3}$ [4,16], are mutually compatible. Importantly, EDS analysis on the cross-section indicated that no detectable chromium penetration into the protection layer had occurred after a duration of 100 hours at $800^{\circ} \mathrm{C}$.

The same approach was also used to fabricate a $\mathrm{Mn}_{1.5} \mathrm{Co}_{1.5} \mathrm{O}_{4}$ protection layer onto AISI430 (Figure 7). As in the case for Crofer22APU, the protection layer acted as an effective $\mathrm{Cr}$ barrier during the 100 hours of heat treatment. 


\section{Performance and Stability}

\section{(A) Electrical Performance and Thermomechanical Stability}

Stainless steel samples with spinel protection layers were first evaluated in a configuration (described in Reference 26) which simulates the interconnect/cathode structure in SOFC stacks. Porous LSF layers, representing the cathodes, were fabricated onto both sides of a dense, $2 \mathrm{~mm}$ thick LSF substrate via screen-printing of LSF ink and subsequent sintering at $1150^{\circ} \mathrm{C}$ in air. (For the balance of this paper, these porous LSF layers will be referred to as cathodes, although in these symmetrical ASR tests, no cathodic processes were occurring). The LSF substrate with cathodes was then sandwiched symmetrically between two Crofer22 APU coupons, representing the interconnects, that had been screen-printed with the spinel-forming ink and subsequently heat-treated in a reducing environment. A contact layer of LSCM $\left(\mathrm{La}_{0.8} \mathrm{Sr}_{0.2} \mathrm{Co}_{0.5} \mathrm{Mn}_{0.5} \mathrm{O}_{3}\right)$ ink was applied between the Crofer22 APU coupons and cathodes. During tests, a dead load of 6.5 psi was uniformly applied to the "sandwich" in order to promote interfacial contact. A four point resistance technique was adopted to determine the resistance of the interconnect/cathode assembly. A current density of $0.5 \mathrm{~A} . \mathrm{cm}^{-2}$ was applied during the test, while the voltage was monitored as a function of time. The contact area-specific resistance (ASR) between a cathode and an interconnect was obtained by dividing the measured ASR by two (due to the symmetrical test design). Both isothermal and thermal cyclic (from room temperature to $800^{\circ} \mathrm{C}$ at a rate of $5^{\circ} \mathrm{C} / \mathrm{min}$ ) tests were performed.

Figure 8 shows the contact ASR for Crofer22 APU with the spinel protection layer as a function of time at $800^{\circ} \mathrm{C}$ in air, in comparison with that of unprotected Crofer $22 \mathrm{APU}$. For the unprotected Crofer22 APU, the contact ASR increased steadily to 39 mohm. $\mathrm{cm}^{2}$ after 400 hours. In contrast, the ASR for the Crofer22 APU with the spinel protection layer had a low initial value $\left(\sim 17\right.$ mohm.cm $\left.{ }^{2}\right)$ which subsequently decreased to $\sim 13$ mohm.cm ${ }^{2}$ after 400 hours. The lower interfacial ASR and its decreasing trend with time is tentatively attributed to the high electrical conductivity of the manganese cobalt spinel, and interactions between the protection layer and the contact material, which led to an improved electrical contact over time between these two layers. The observed contact ASR was lower than previously reported for perovskite overlay coatings, which increased with time [40,41]. 
After the short-term test, SEM analysis on the cross-section of the tested sample confirmed that the spinel layer was well-bonded to the Crofer22 APU and free of spallation or cracks. A smooth, continuous interface was observed between the protection layer and the sub-scale grown on the stainless steel. Again EDS found no evidence of $\mathrm{Cr}$ penetration through the protection layer into either the LSCM contact layer or the LSF cathode. In contrast, 6.0 10.0 wt\% Cr was generally detected in the LSCM contact layer between the bare (unprotected) Crofer22 APU and LSF cathode, and 2.0 3.0 wt\% $\mathrm{Cr}$ in the LSF cathode, after 400 hours of testing.

To examine its long-term performance and thermomechanical stability, Crofer22 APU with the thermally grown spinel protection layers was further tested for a period of six months under a total of 125 thermal cycles (plus three occurrences of unscheduled power failure). During this test (see Figure 9), the contact ASR between the LSF cathode and the metallic interconnect at $800^{\circ} \mathrm{C}$ steadily decreased from the starting value of $15.0 \mathrm{mohm} . \mathrm{cm}^{2}$ to 14.3 mohm. $\mathrm{cm}^{2}$, demonstrating excellent stability. SEM analysis on the cross-section of the tested sample at the edge areas, where there was no contact paste applied, as shown in Figure 10(a), indicated good thermomechanical stability of the thermally-grown protection layers. No spallation or chipping was observed, and the sub-scale only grew to a thickness $\sim 2.0 \mu \mathrm{m}$. In contrast, as shown in Figure 10(b), spallation or chipping was observed on the portion of the Crofer22 APU without a protection layer, and the scale grew to a thickness over $10 \mu \mathrm{m}$, which is consistent with previous work [16]. The spalled fragments were identified by EDS point analysis to be primarily $(\mathrm{Mn}, \mathrm{Cr})_{3} \mathrm{O}_{4}$ spinel. Thus, the spinel protection layer on Crofer22 APU not only drastically reduced the interfacial ASR, but also inhibited the scale growth on the ferritic stainless steel by limiting oxygen ion diffusion inward through the spinel layer. The excellent thermomechanical stability and stable electrical performance are attributed to the inhibited subscale growth, an improved strain tolerance of the porous microstructure, and a good thermal expansion match between the spinel and the metal substrate.

Also, unlike many overlay coatings such as perovskites $[9,25,41]$, the spinel protection layer acted as an effective mass transport barrier in stopping chromium migration from the metal. EDS analysis (see Figure 11) revealed a sharp Cr profile across the interface between the subscale and the spinel protection layer, with no chromium detectable in the spinel protection layer and at its surface after the six months thermal cycling test. No Cr was found in the LSCM 
contact and the LSF cathode. For example, the EDS analysis of the contact layer at point "A" in Figure 7 indicated $18 \% \mathrm{Mn}, 6.0 \% \mathrm{Co}, 17.0 \% \mathrm{La}, 7.0 \% \mathrm{Sr}, 52 \% \mathrm{O}$, and no Cr.

As verified by both the short- and long-term tests, the manganese cobaltite spinel protection layers thermally grown on ferritic stainless steel interconnects appear to be very effective in improving the surface stability and electrical conductivity of these metallic interconnect materials, and in preventing outward chromium cation diffusion to the interconnect surface.

\section{(B) Stability During Cell Test}

In addition to the ASR and thermomechanical stability evaluations, the spinel protection layers were further examined for their effect on the stability of electrochemical performance of an anode-supported SOFC. The cell was fabricated with a Ni-YSZ anode, thin-film YSZ electrolyte, and $\mathrm{La}_{0.8} \mathrm{Sr}_{0.2} \mathrm{FeO}_{3}$ (LSF) cathode, as well as a $\mathrm{Ce}_{0.8} \mathrm{Sm}_{0.2} \mathrm{O}_{1.9}$ interlayer $(\sim 5 \mu \mathrm{m}$ sintered thickness) between the cathode and electrolyte. A piece of stainless steel with the $\mathrm{Mn}_{1.5} \mathrm{Co}_{1.5} \mathrm{O}_{4}$ protection layer [18] was used as the cathode current collector, and applied to the cathode (under a compressive load) with Pt paste. Precise cell fabrication and testing techniques are detailed in an earlier publication [42].

Overall the cell tests indicated the effectiveness of the $(\mathrm{Mn}, \mathrm{Co})_{3} \mathrm{O}_{4}$ spinel protection layers in stopping chromium migration from the ferritic stainless steel interconnects and thus preventing cathode poisoning. As an example, Figure 12 shows the electrochemical performance of a cell with a Crofer22 APU cathode current collector with the spinel protection layer, in comparison with that of a cell with an unprotected Crofer22 APU current collector. The data (obtained at $0.7 \mathrm{~V} / 750^{\circ} \mathrm{C}$ ) show a rapid degradation of the cell with the unprotected Crofer22 APU current collector. SEM/EDS analysis on the cross-section of the tested sample indicated $1 \sim 3$ atomic \% $\mathrm{Cr}$ in the LSF cathode and the ceria interlayer between the cathode and the YSZ electrolyte. Chromium migration into a LSF cathode was also observed by Simner et al. [43] when a perovskite conductive oxide contact material was used. In contrast, the cell with the Crofer22 APU that was protected by the thermally grown $\mathrm{Mn}_{1.5} \mathrm{Co}_{1.5} \mathrm{O}_{4}$ spinel layer also experienced an initial drop in performance but then exhibited a cathode conditioning effect [44], which was followed by stable performance. SEM/EDS analysis on the cross-section of this cell 
found no $\mathrm{Cr}$ deposition or migration into the LSF cathode and the ceria interlayer. While the mechanisms behind the behavior of the two cells are complicated [45], the correlation between stable/unstable performance and the absence/presence of $\mathrm{Cr}$ in the cell is apparent.

Thus it appears that the thermally grown $\mathrm{Mn}_{1.5} \mathrm{Co}_{1.5} \mathrm{O}_{4}$ spinel protection layer on the ferritic stainless steel acted effectively as a barrier to outward diffusion of chromium from the steel. Both the prevention of chromium migration and decreased ASR (as indicated by the ASR tests described above) likely contributed to the improved electrochemical performance observed in the cell with the spinel-protected current collector.

\section{Summary}

The $(\mathrm{Mn}, \mathrm{Co})_{3} \mathrm{O}_{4}$ spinel with a nominal composition of $\mathrm{Mn}_{1.5} \mathrm{Co}_{1.5} \mathrm{O}_{4}$ demonstrates an excellent electrical conductivity and thermal expansion match to ferritic stainless steel interconnects. A slurry coating approach appears to a viable means of fabricating protective layers of the spinel onto the steel interconnects. Thermally grown protection layers of $\mathrm{Mn}_{1.5} \mathrm{Co}_{1.5} \mathrm{O}_{4}$ not only significantly decreased the contact resistance between a LSF cathode and the stainless steel interconnect, but also inhibited the sub-scale growth on the stainless steel. The combination of the inhibited sub-scale growth, good thermal expansion matching between the spinels and the stainless steel, and the closed-pore structure may contribute to the excellent structural and thermomechanical stability of these spinel protection layers, which was verified by a long-term thermal-cycling test. The spinel protection layers can also act effectively to prevent outward diffusion of chromium from the interconnect alloy, preventing subsequent chromium migration into the cathode and contact materials. PNNL is currently engaged in studies intended to optimize the composition, microstructure, and fabrication procedure for the spinel protection layers.

\section{Acknowledgements}

The authors would like to thank Nat Saenz, Shelly Carlson, and Jim Coleman for their assistance in metallographic and SEM sample preparation and analysis. The work summarized in this paper was funded as part of the Solid-State Energy Conversion Alliance (SECA) Core Technology Program by the U.S. Department of Energy's National Energy Technology 
Laboratory (NETL). The authors would like to acknowledge helpful discussions with Wayne Surdoval, Lane Wilson, Don Collins, and Travis Schulz. PNNL is operated by Battelle Memorial Institute for the U.S. Department of Energy under Contract DE-AC06-76RLO 1830.

\section{References}

1. M. Dokiya, Solid State Ionics, 152-153, 383 (2002).

2. B.C.H., Steele, Nature, 414, 345 (2001).

3. S.P.S. Badwal, R. Bolden, and K. Foger, in Proc. $3^{\text {rd }}$ Eur. SOFC Forum, P. Stevens, Editor, p. 105, European Solid Oxide Fuel Cell Forum, Switzerland (1998).

4. W.J. Quaddakkers, J. Piron-Abellan, V. Shemet, and L. Singheiser, Materials of High Temperature, 20, 115 (2003).

5. Z. Yang, K.S. Weil, D.M. Paxton, and J.W. Stevenson, J. Electrochem. Soc., 150, A1188 (2003).

6. T. Malkow, U.V.D. Crone, A.M. Laptev, T. Koppitz, U. Breuer, and W.J. Quadakkers, in Solid Oxide Fuel Cells, U. Stimming, S.C. Singal, H. Tagawa, and W. Lehnert, Editors, PV 97-40, p. 1244, The Electrochemical Society, Pennington, NJ (1997).

7. C. Gindorf, L. Singheiser, and K. Hilpert, Steel Res., 72, 528 (2001).

8. C. Gindorf, L. Singheiser, and K. Hilpert, M. Schroeder, M. Martin, H. Greiner, and F. Richter, in Solid Oxide Fuel Cells, S.C. Singal and M. Dokiya, Editors, PV 99-19, p. 774, The Electrochemical Society, Pennington, NJ (1999).

9. K. Hilpert, D. Das, M. Miller, D.H. Peck, and R. Weiß, J. Electroch. Soc., 143, 3642 (1996).

10. S.C. Paulson and V.I. Birss, J. Electrochem. Soc., 151, A1961 (2004).

11. S. Taniguchi, M. Kadowaki, H. Kawamura, T. Yasuo, Y. Akiyama, and Y. Miyaki, J Power Sour., 55, 73 (1995).

12. Y. Matsuzaki and I. Yasuda, J. Electrochem. Soc., 148, A126 (2001).

13. J.-Y. Kim, N.L. Canfield, L.A. Chick, K.D. Meinhardt, and V.L. Sprenkle, Proceedings of $29^{\text {th }}$ Inter. Conf. on Adv. Ceramics and Composites, ACeRS, 2005 (in press).

14. W.J. Quadakkers, V. Shemet, and L. Singheiser, US Paten No. 2003059335 (2003).

15. J.P. Abeilan, V. Shemet, F. Tietz, L. Singheiser, and W.J. Quadakkers, in Proceedings of the $7^{\text {th }}$ International Symposium on Solid Oxide Fuel Cells, S.C. Singhal and M. Dokiya, Editors, PV200116, p. 811, The Electrochemical Proceedings Series, Pennington, NJ (2001).

16. Z. Yang, J.S. Hardy, M.S. Walker, G. Xia, S.P. Simner, and J.W. Stevenson, J. Electrochem. Soc., 151, A1825 (2004). 
17. E. Konycheva, H. Penkalla, E. Wessel, U. Seeling, L. Singheiser, and K. Hilpert, in Proceedings of the $9^{\text {th }}$ International Symposium on Solid Oxide Fuel Cells, S.C. Singhal and J. Mizusaki, Editors, PV2005-07, p. 1874, The Electrochemical Proceedings Series, Pennington, NJ (2005).

18. S.P. Simner, M.D. Anderson, G. Xia, Z. Yang and J.W. Stevenson, submitted to J. Electrochem. Soc., 2004.

19. Z. Yang, M.S. Walker, P. Singh, and J.W. Stevenson, J. Electrochem. Soc., 151, B669 (2004).

20. Z. Yang, G.-G. Xia, P. Singh, and J.W. Stevenson, Solid State Ionics, 2005 (in press).

21. W.J. Quaddakers, H. Greiner, M. Hansel, A. Pattanaik, A.S. Khanna, and W. Mallener, Solid Stste Ionics, 91, 55 (1996).

22. T. Kadowaki, T. Shiomitsu, E. Matsuda, H. Nakagawa, and H. Tsuneisumi, Solid State Ionics, 67, 65 (1993).

23. Y. Yoo and M. Dauga, in Proceedings of the $7^{\text {th }}$ International Symposium on Solid Oxide Fuel Cells, S.C. Singhal and M. Dokiya, Editors, PV2001-16, p. 837, The Electrochemical Proceedings Series, Pennington, NJ (2001).

24. S. Elangovan, S. Balagopal, M. Timper, I. Bay, D. Larsen, and J. Hartvigsen, J. Mater. Eng. \& Perfor., 13, 265 (2004).

25. Y. Larring and T. Norby, J. Electrochem., Soc., 147, 3251 (2000).

26. Z. Yang, G. Xia, and J.W. Stevenson, Electrochem. \& Solid-State Lett., 8, A168 (2005).

27. Z. Yang, G.-G. Xia, S.P. Simner, and J.W. Stevenson, J. Electrochem. Soc., in press.

28. Z. Yang, G.-G. Xia, M.S. Walker, P. Singh, J.W. Stevenson, G.-G. Xia, Proceedings of SECA Annual Workshop and Core Technology Program Peer Review Workshop, Boston, MA, May 11-13: http://www.seca.doe.gov.

29. Z. Yang, G.D. Maupin, S.P. Simner, P. Singh, J.W. Stevenson, G.-G. Xia, Proceedings of SECA Core Technology Peer Review Workshop, Tampa, FL, Jan 27-28, 2005: Http://www.seca.doe.gov.

30. Z. Yang, G.D. Maupin, S.P. Simner, P. Singh, J.W. Stevenson, G.-G. Xia, Proceedings of 6th SECA Annual Workshop, Monterey, CA, April 18, 2005: Http://www.seca.doe.gov.

31. S. Naka, M. Inagaki, and T. Tanaka, J Mater. Sci., 7, 441 (1972).

32. J.L. Gautier, C. Cabezas, S. Barbato, Electrochim. Acta., 26, 1377 (1981).

33. A. Restovic, E. Rios, S. Barbato, J. Ortiz, and J.L. Gautier, J Electroanalyt. Chem., 522, 141 (2002).

34. JCPDS-International Centre for Diffraction Data, \#23-1237.

35. JCPDS-International Centre for Diffraction Data, \#18-0408.

36. E. Aukrust and A. Muan, J. Am. Ceram. Soc., 46, 511 (1963).

37. T. Sasamoto, N. Sumi, A. Shimaji, O. Yamamoto, and Y. Abe., J. Mater. Sci. Soc. Japan, 33, 32 (1996). 
38. A. Holt and P. Kofstad, Solid State Ionics, 69, 137 (1994).

39. L.A. Chick, L.R. Pederson, G.D. Maupin, J.L. Bates, L.E. Thomas, and G.L. Exarhos, Mater. Lett., 10, 6 (1990).

40. E. Konycheva, J. Laatsch, E. Wessel, F. Tietz, N. Christiansen, L. Singheiser, and K. Hilpert, in Proc. $6^{\text {th }}$ Eur. SOFC Forum, M. Mogensen, Editor, p. 1586, European Solid Oxide Fuel Cell Forum, Switzerland (2004).

41. Z. Yang, private communication.

42. S.P. Simner, J.F. Bonnett, N.L. Canfield, K.D. Meinhardt, J.P. Shelton, V.L. Sprenkle, and J.W. Stevenson, J. Power Sources, 113, 1 (2003).

43. S.P. Simner, M.D. Anderson, G. Xia, Z. Yang, and J.W. Stevenson, J. Electrochem. Soc., 152, A740 (2005).

44. S.P. Simner, J.W. Stevenson, K.D. Meinhardt, and N.L. Canfield, in the Proceedings of $7^{\text {th }}$ International Symposium on Solid Oxide Fuel Cells, H. Yokokawa and M. Dokiya, Editors, PV200116, p. 1051, The Electrochemical Proceedings Series, Pennington, NJ (2001).

45. S.P. Simner, M.D. Anderson, L.R. Pederson, and J.W. Stevenson, in preparation. 
(a) $\mathrm{MnCo}_{2} \mathrm{O}_{4}$

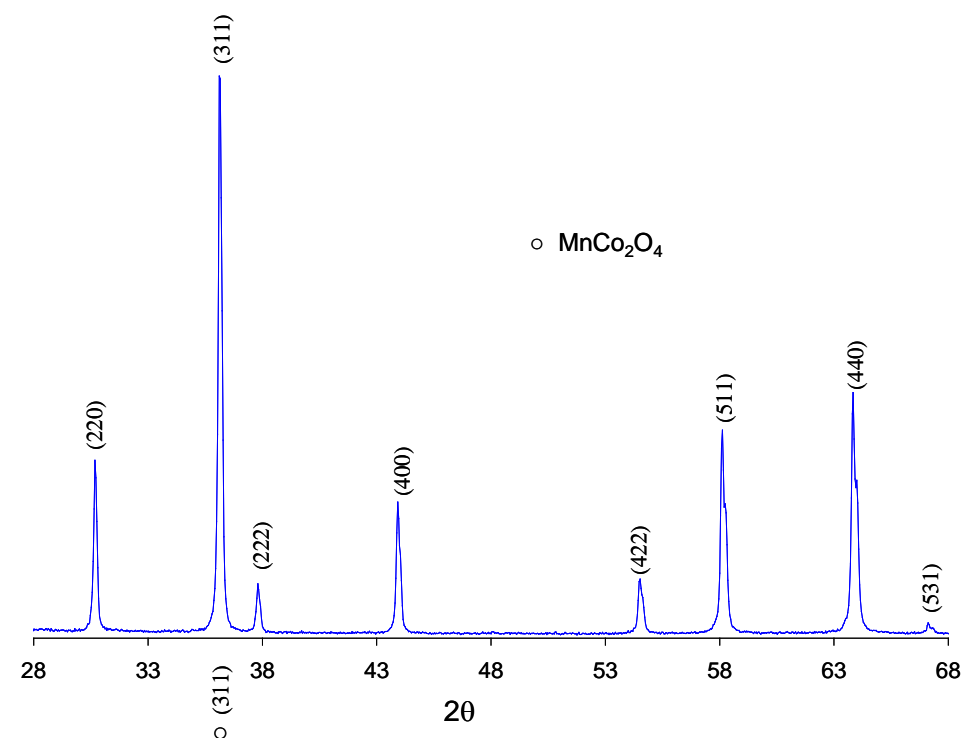

(b) $\mathrm{Mn}_{1.5} \mathrm{Co}_{1.5} \mathrm{O}_{4}$

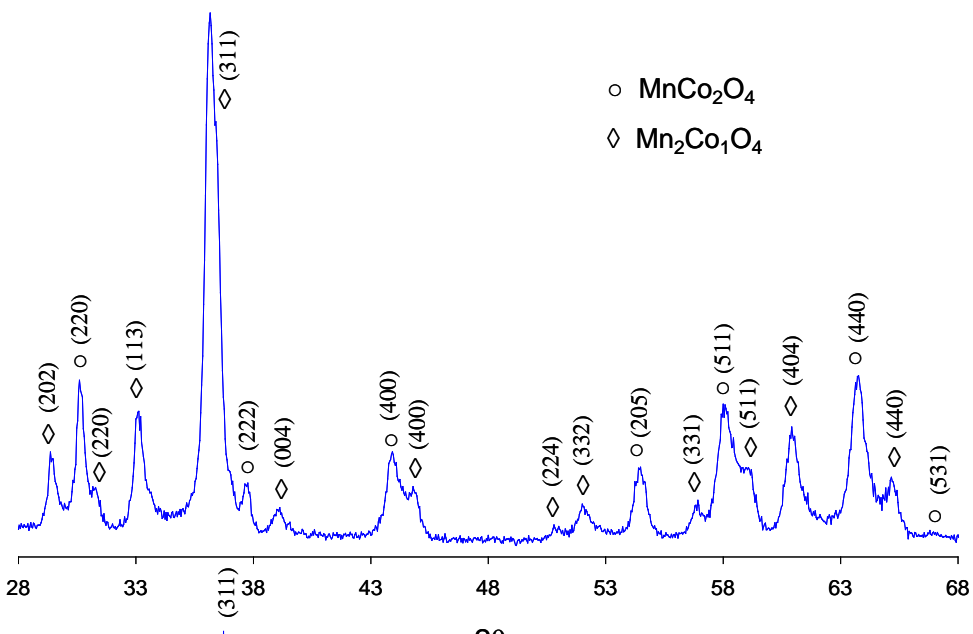

(c) $\mathrm{Mn}_{2} \mathrm{CoO}_{4}$

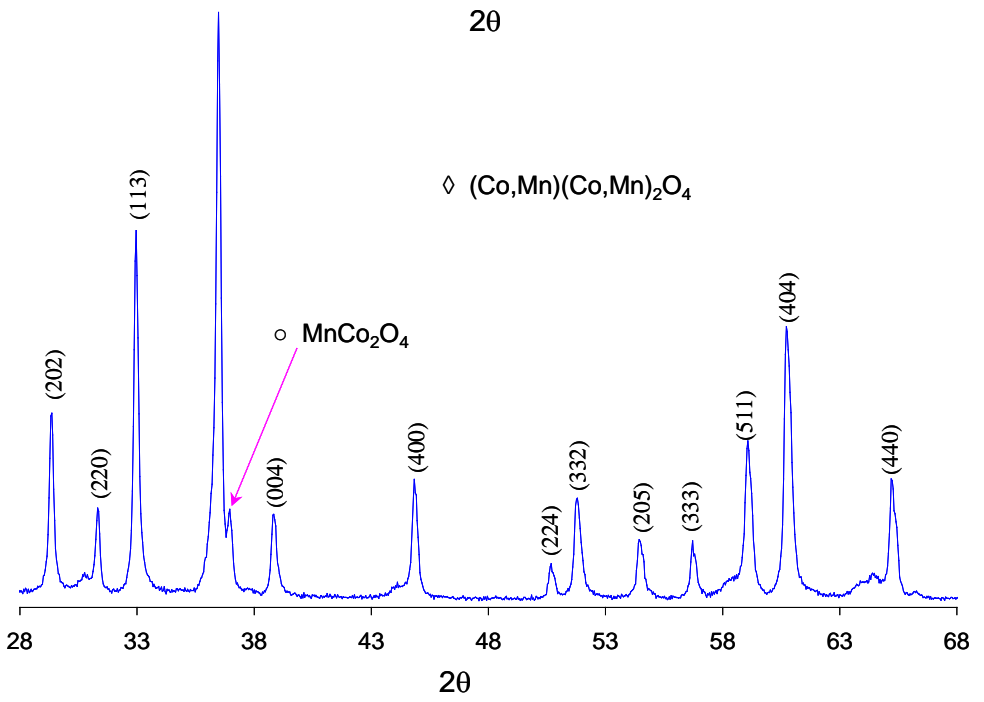

Figure 1. X-ray diffraction patterns of (a) $\mathrm{MnCo}_{2} \mathrm{O}_{4}$, (b) $\mathrm{Mn}_{1.5} \mathrm{Co}_{1.5} \mathrm{O}_{4}$, and (c) $\mathrm{Mn}_{2} \mathrm{CoO}_{4}$, all of which were synthesized via a glycine-nitrate process, followed by calcination at $800^{\circ} \mathrm{C}$ for 4 hours in air. 


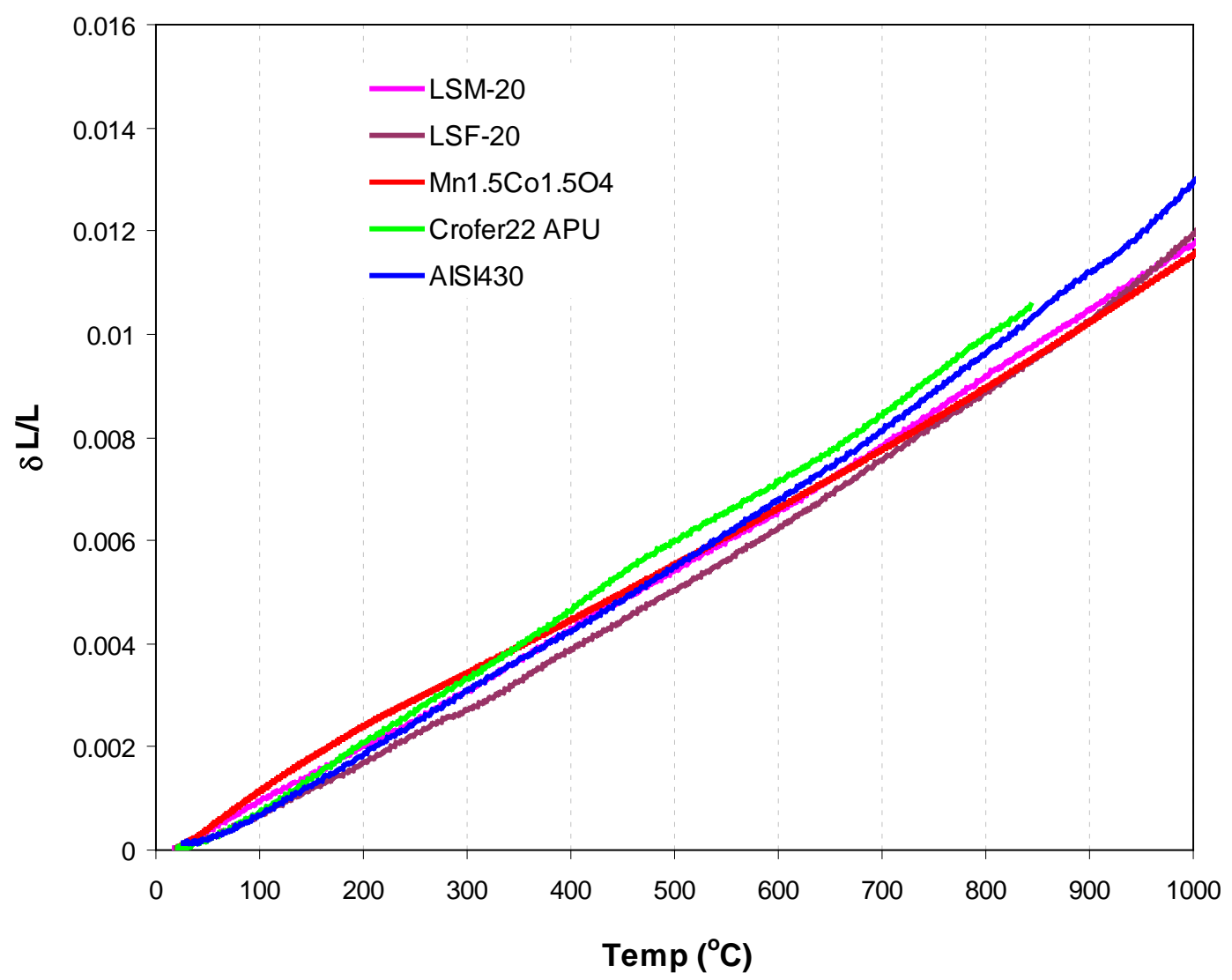

Figure 2. Thermal expansion behavior of $\mathrm{Mn}_{1.5} \mathrm{Co}_{1.5} \mathrm{O}_{4}$, in comparison with that of $\mathrm{La}_{0.8} \mathrm{Sr}_{0.2} \mathrm{MnO}_{3}$, $\mathrm{La}_{0.8} \mathrm{Sr}_{0.2} \mathrm{FeO}_{3}$, Crofer22 APU and AISI430. 


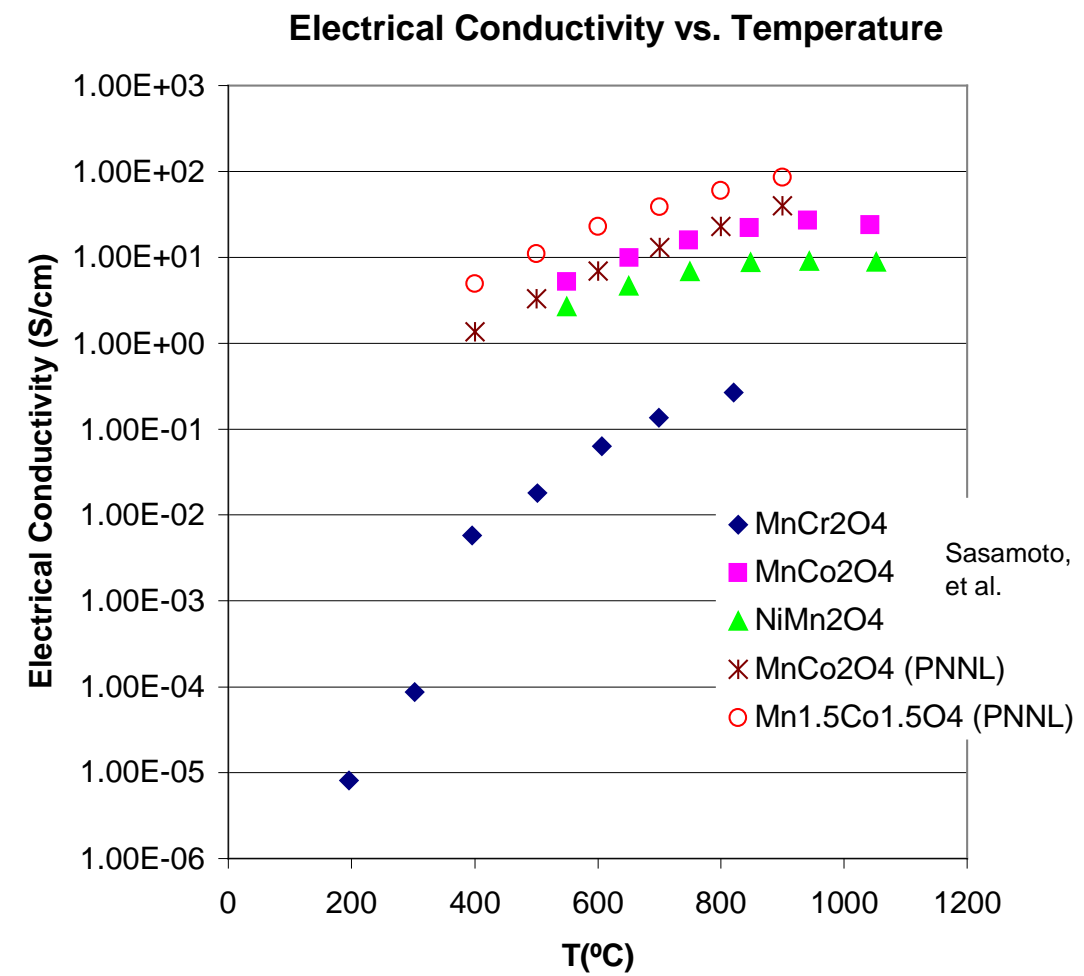

Figure 3. Electrical conductivity of transition metal oxide spinels measured at PNNL, in comparison with reported data [37]. 


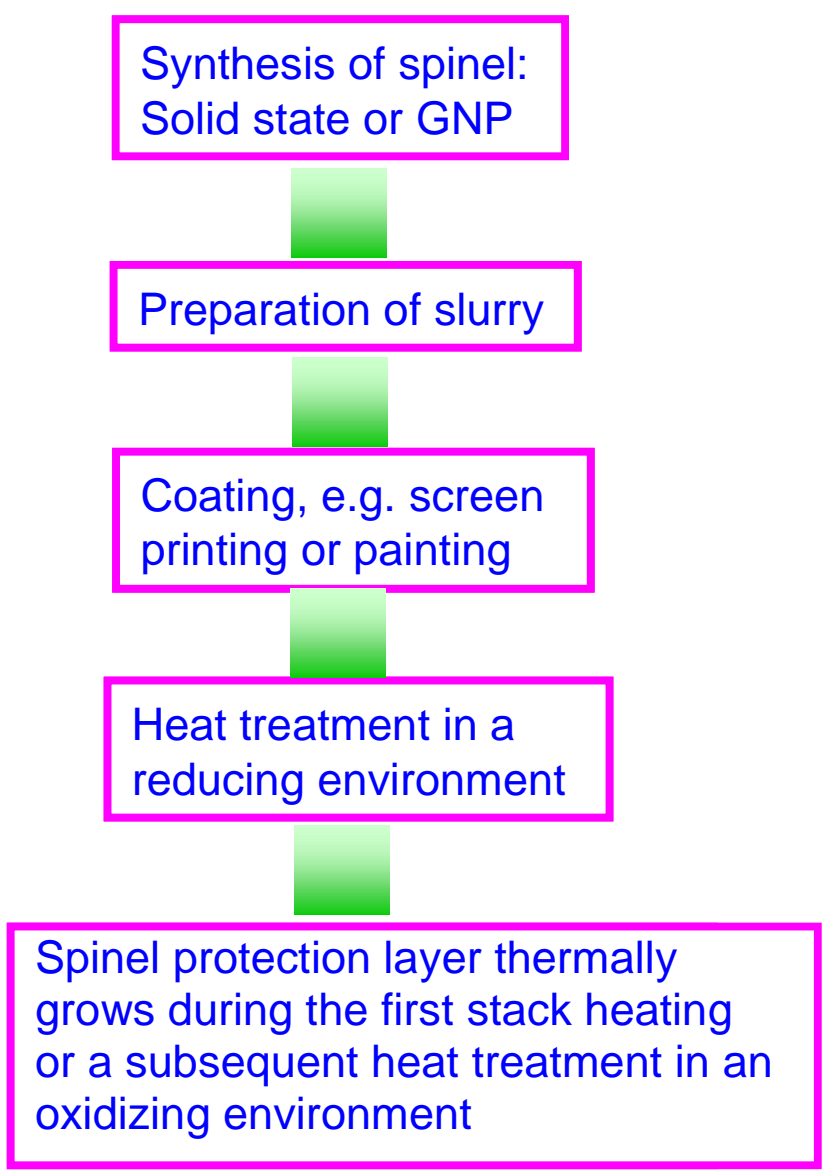

Figure 4. Flow chart for fabrication of spinel protection layers on ferritic stainless steel interconnects via slurry coatings. 


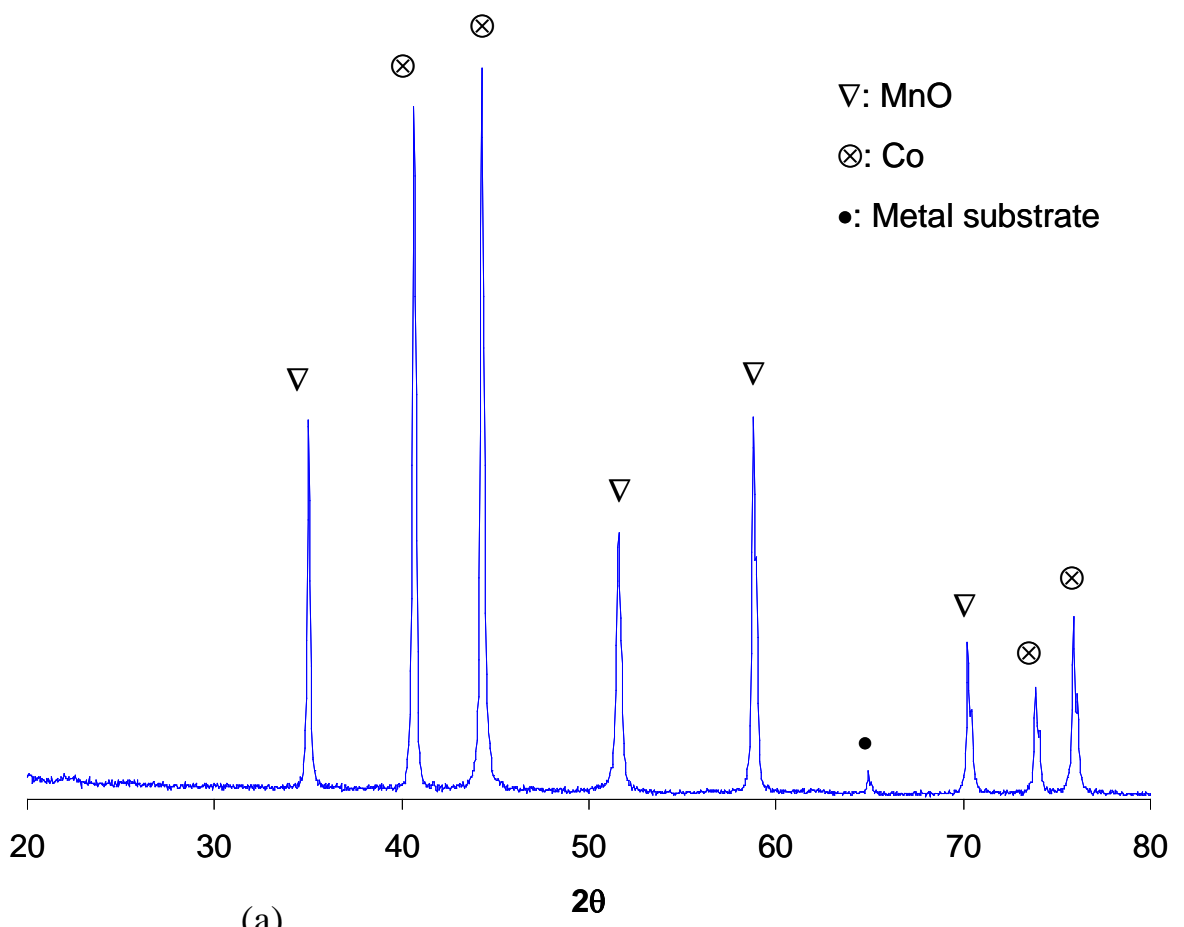

(a)

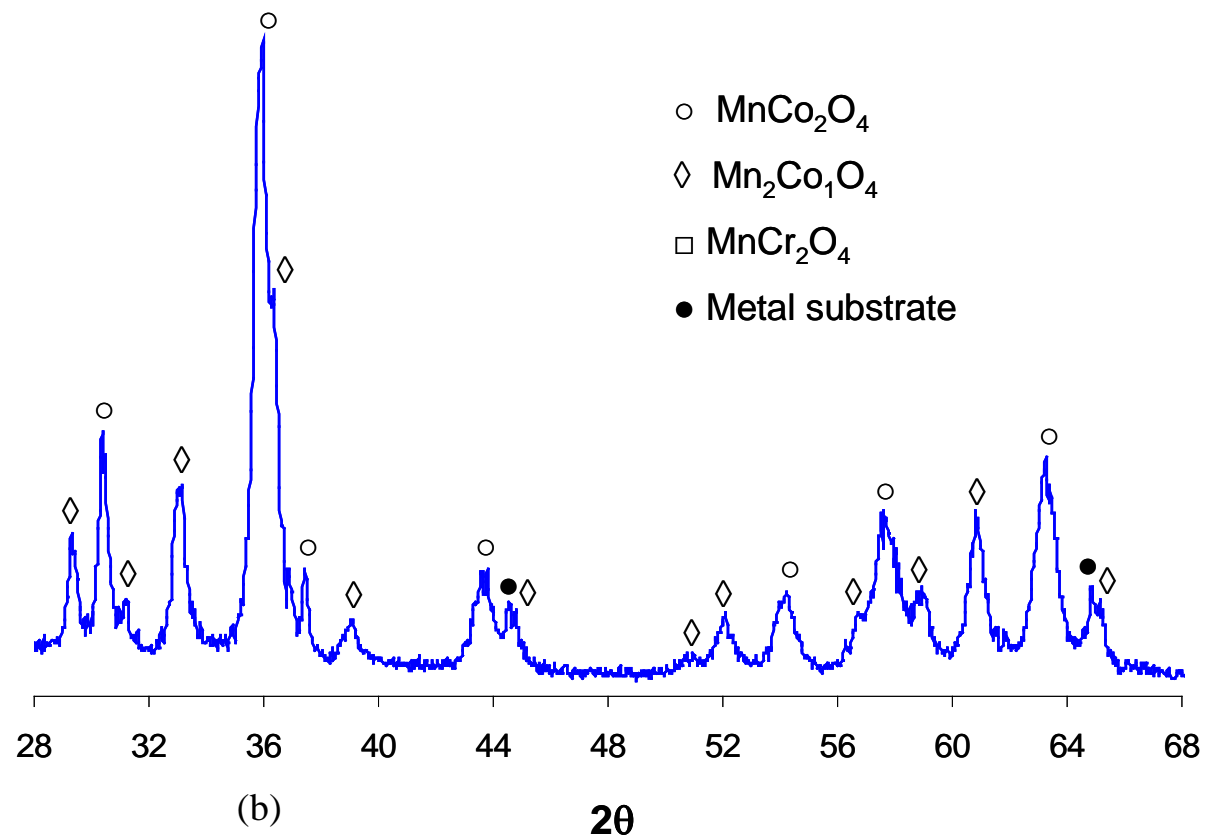

Figure 5. X-ray diffraction patterns of protection layers on Crofer22 APU: (a) after a heat-treatment at $800^{\circ} \mathrm{C}$ for 24 hours in $2.75 \% \mathrm{H}_{2} / \mathrm{bal}$. Ar, (b) after the subsequent oxidation at $800^{\circ} \mathrm{C}$ in air for 100 hours. 

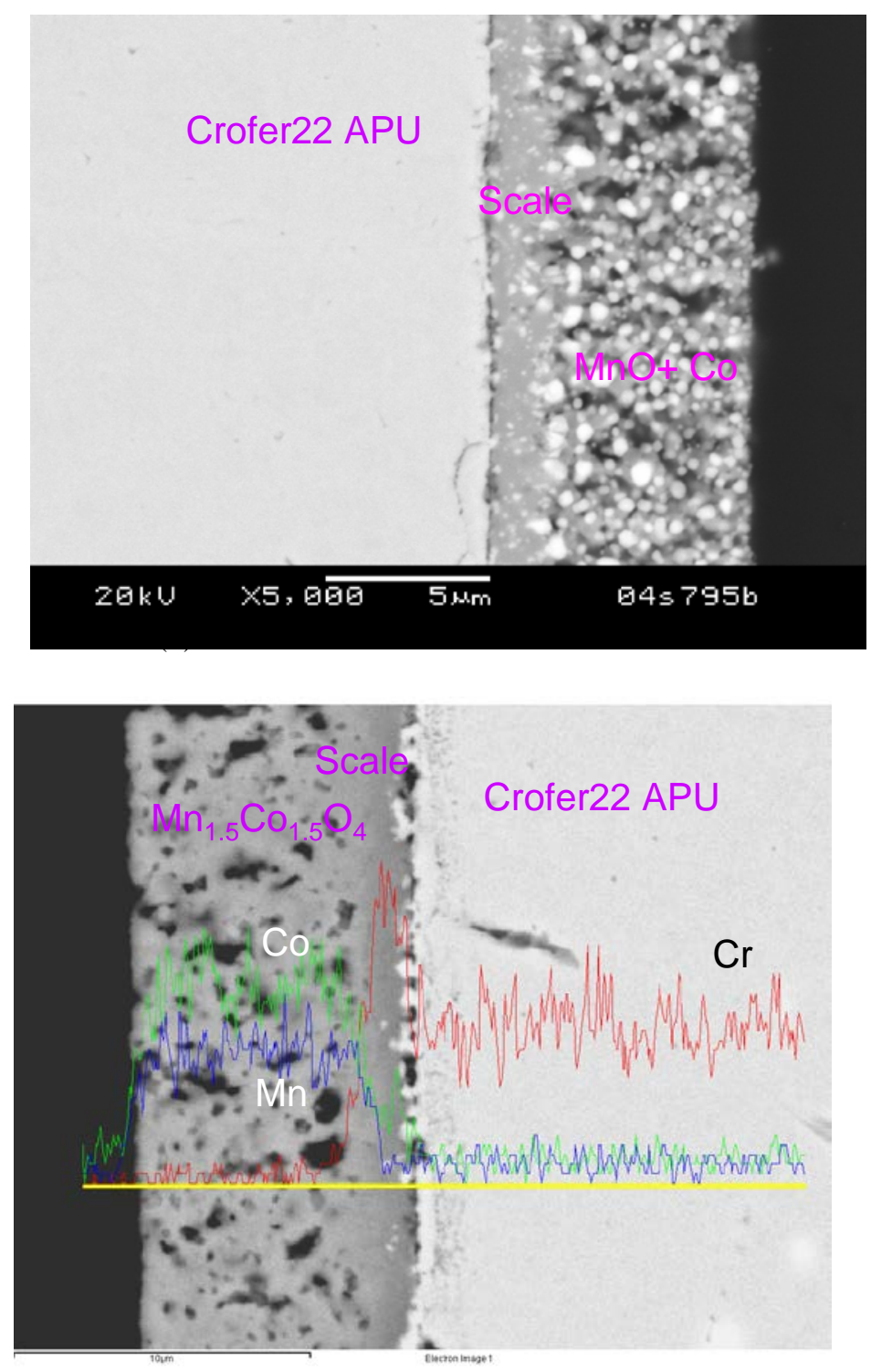

(v)

Figure 6. SEM images of cross-sections of protection layers on Crofer22 APU: (a) after a heat-treatment at $800^{\circ} \mathrm{C}$ for 24 hours in $2.75 \% \mathrm{H}_{2} / \mathrm{bal}$. Ar, (b) after the subsequent oxidation at $800^{\circ} \mathrm{C}$ in air for 100 hours. 


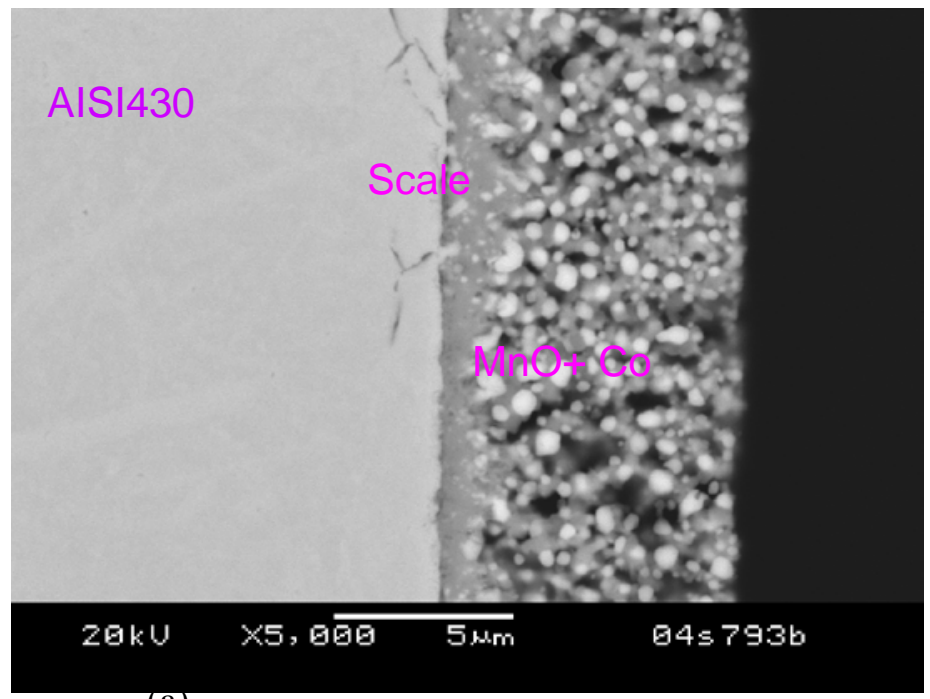

(a)

(b)

Figure 7. SEM images of cross-sections of protection layers on AISI430: (a) after a heat-treatment at $800^{\circ} \mathrm{C}$ for 24 hours in $2.75 \% \mathrm{H}_{2} / \mathrm{bal}$. Ar, (b) after the subsequent oxidation at $800^{\circ} \mathrm{C}$ in air for 100 hours. 


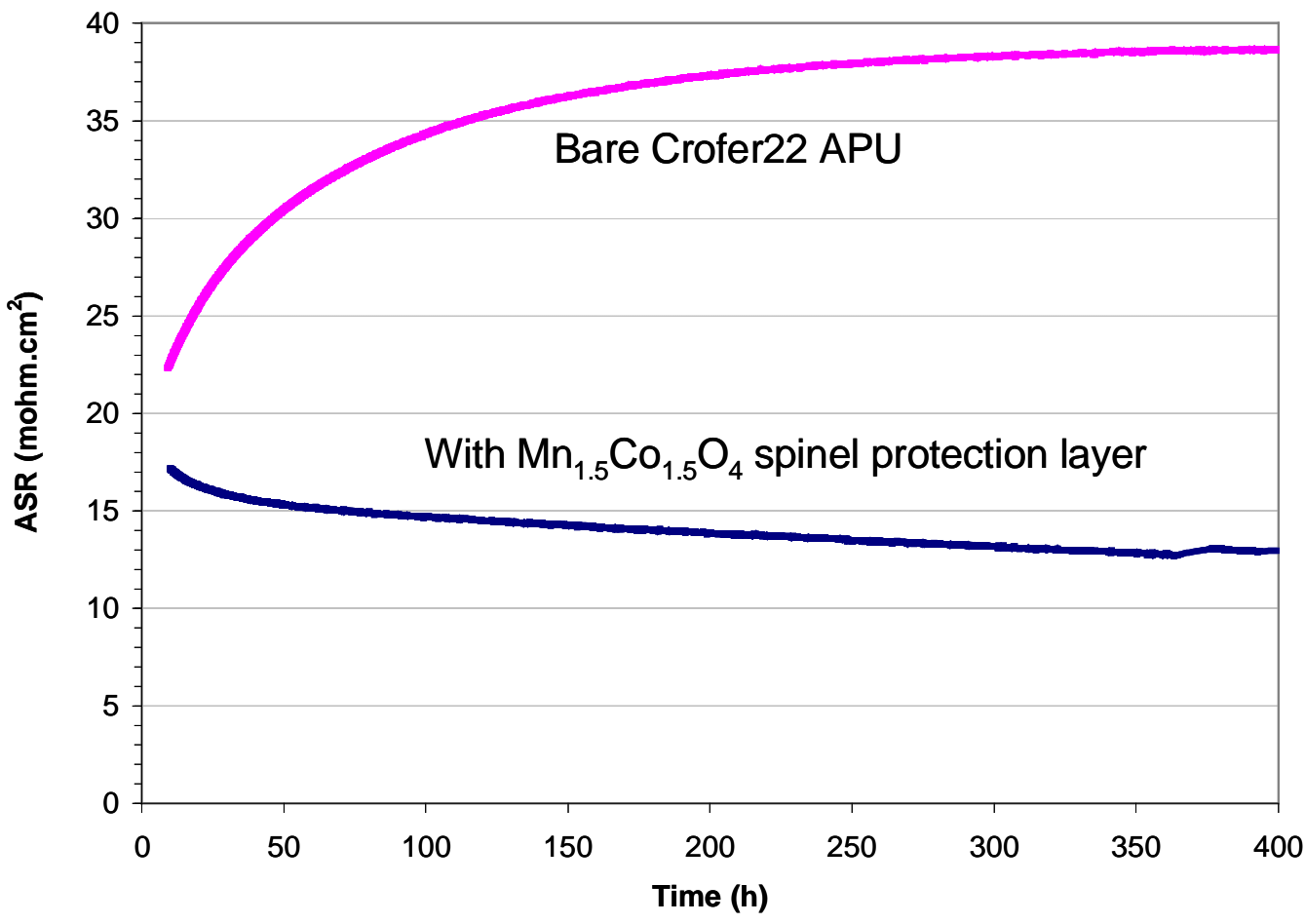

Figure 8. Interfacial ASR between a LSF cathode and a Crofer22 APU current collector with and without the spinel protection layer. Temperature $-800^{\circ} \mathrm{C}$, Exposure atmosphere - air. 


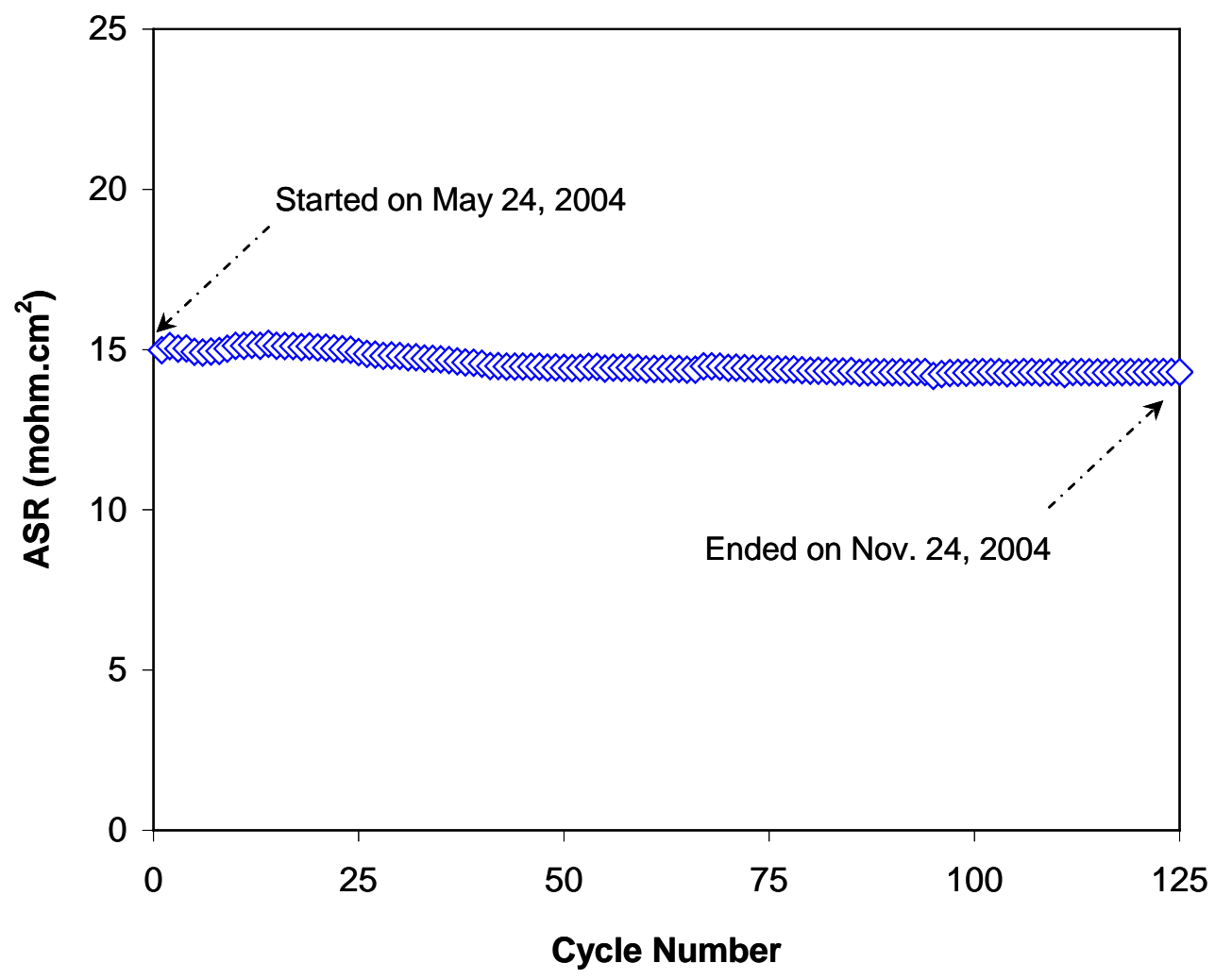

Figure 9. Contact ASR of $\mathrm{La}_{0.8} \mathrm{Sr}_{0.2} \mathrm{FeO}_{3}|| \mathrm{La}_{0.8} \mathrm{Sr}_{0.2} \mathrm{Co}_{0.5} \mathrm{Mn}_{0.5} \mathrm{O}_{3} \|$ Crofer22 APU as a function of thermal cycle numbers. The Crofer22 APU was screen-printed with the $\mathrm{Mn}_{1.5} \mathrm{Co}_{1.5} \mathrm{O}_{4}$ spinel paste and then heattreated at $800^{\circ} \mathrm{C}$ in the reducing environment for 24 hours before being placed in the test stand and continuously tested for six months. 


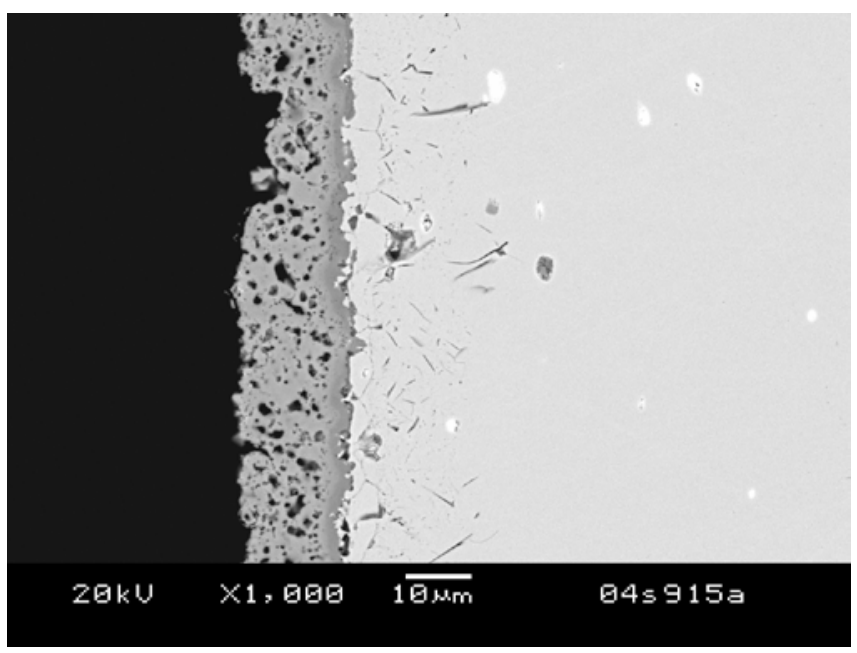

(a)

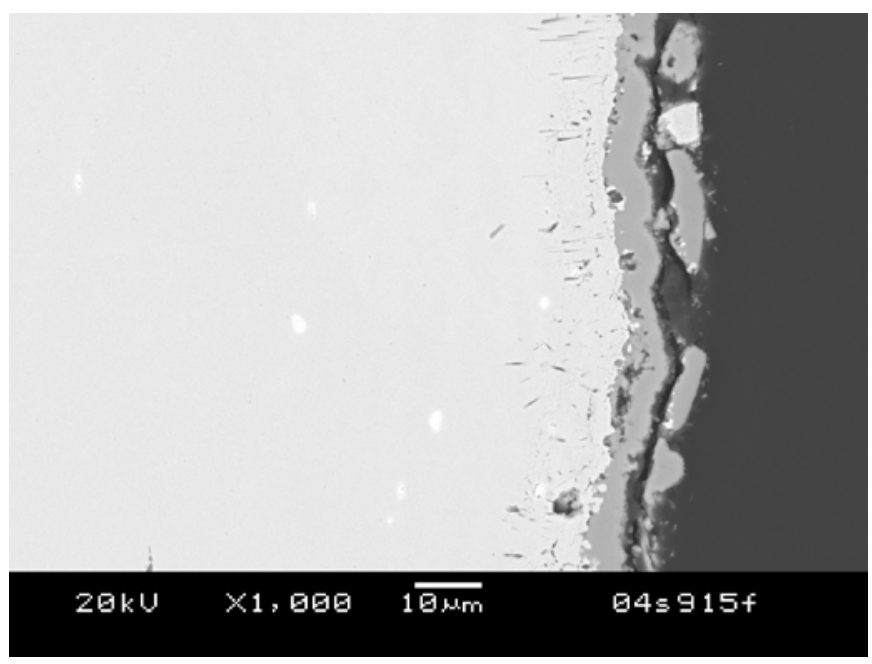

(b)

Figure 10. SEM images of the cross-section of Crofer22 APU after testing for 6 months including over 125 thermal cycles: (a) at the side with a thermally grown $\mathrm{Mn}_{1.5} \mathrm{Co}_{1.5} \mathrm{O}_{4}$ spinel protection layer and (b) at the side without protection. 


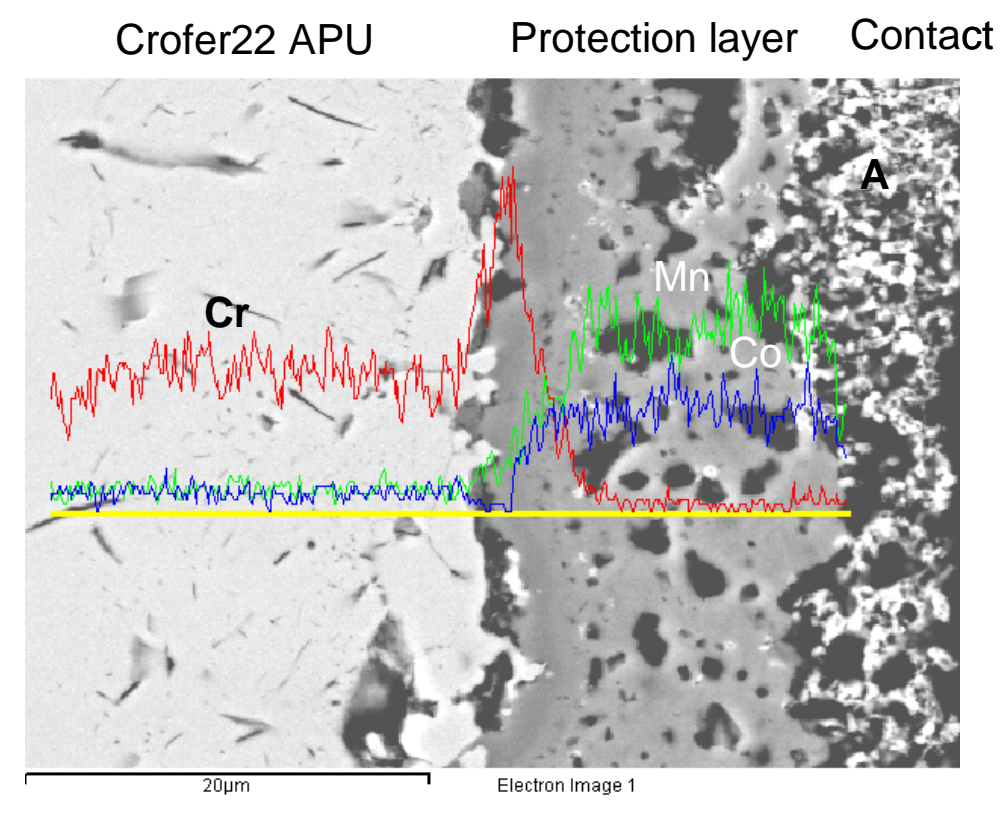

Figure 11. Microstructural and compositional analyses on the $\mathrm{Mn}_{1.5} \mathrm{O}_{1.5} \mathrm{O}_{4}$ protection layer subjected to a contact ASR measurement for a period of six months including thermal cycling. 


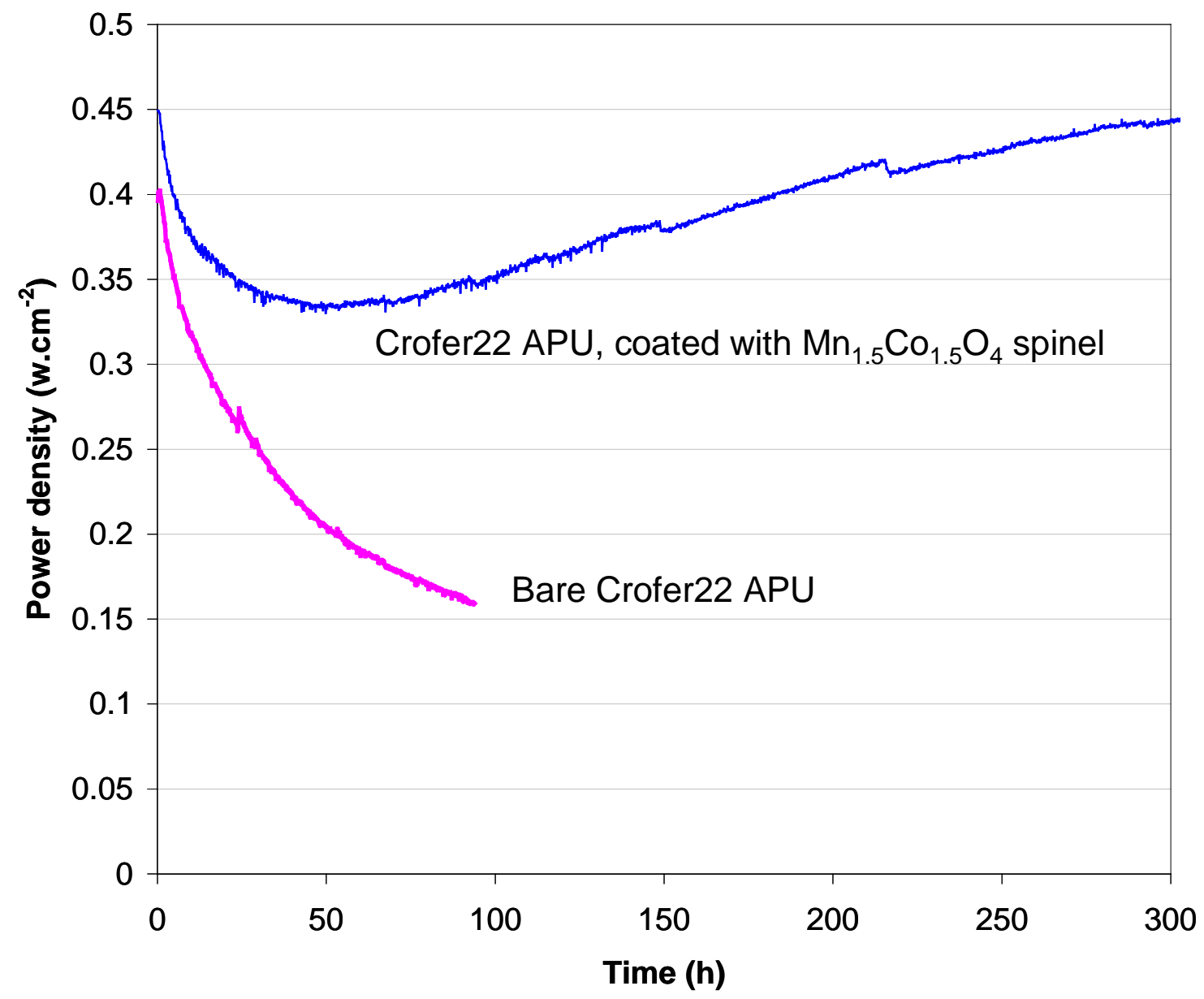

Figure 12. Electrical performance behavior of cells utilizing bare and protected current collectors:

With unprotected current collector, cell shows rapid performance degradation

With spinel protected current collector, cell performance improves with time.

Cell attributes: Crofer22 APU cathode current collector, $\mathrm{La}_{0.8} \mathrm{Sr}_{0.2} \mathrm{FeO}_{3}$ cathode, $\mathrm{Sm}$-doped ceria interlayer, YSZ electrolyte and Ni/YSZ anode. 